\title{
Strategic program for landslide disaster risk reduction: a lesson learned from Central Java, Indonesia
}

\author{
D. Karnawati ${ }^{1}$, T. F. Fathani ${ }^{1}$, B. Andayani ${ }^{1}$, P. W. Burton ${ }^{2}$ \\ \& I. Sudarno ${ }^{1}$ \\ ${ }^{I}$ Gadjah Mada University, Indonesia \\ ${ }^{2}$ University of East Anglia, UK
}

\begin{abstract}
The Indonesian Archipelago is one dynamic volcanic arc region, where landslides frequently occur during the rainy season. Not only are geological conditions and high precipitation in the region, but also uncontrolled land use development and high social-vulnerability of the community living in landslide prone areas, that have become the major cause of landslide disasters in Indonesia. Accordingly, a strategic program for landslide risk reduction has been carried out by establishing an appropriate landslide risk management program with respect to social vulnerability. Such programs mainly emphasize the improvement of community resilience in landslide prone areas through community based landslide mitigation and early warning system, as well as public education. Geological investigations combined with social survey and analyses were also carried out to support the implementation of this risk reduction program in Central Java. Finally, it was concluded that the effectiveness of landslide disaster risk reduction was mainly driven by the community empowerment for disaster prevention and mitigation at the village level.
\end{abstract}

Keywords: landslide mitigation, risk reduction, resilience improvement.

\section{Geology and landslide conditions of the study area}

Java, as illustrated in fig. 1, which is modified from [1-3], is a dynamic volcanic island which is predominantly covered by Tertiary to Quartenary andesitic- 
volcanic and carbonaceous-marine sediments with quite intensive structural geology such as fold, faults and joint formation, fig. 2. Interaction of these geological conditions with high rain precipitation (up to $100 \mathrm{~mm} /$ hour or $3000 \mathrm{~mm}$ per year) brings about a high susceptibility of landslides in this region. Fig. 3 illustrates the distribution of landslide susceptibility in Central Java, mainly analyzed based on the morphological and geological conditions. It is apparent that the zone with landslide susceptibility covers about $60 \%$ of the region in Central Java.

Human interferance such as through uncontrolled land use development in such a susceptible region seriously increases the frequency of landslides, especially during heavy rainstorms, as stated by Karnawati et al. [4]. Furthermore, Karnawati and Fathani in [5] also reported that some landslides occurred due to earthquakes, such as those induced by $6.3 \mathrm{Mw}$ Yogyakarta Earthquake of May 27, 2006 along the jointed andesitic and tufaceous rock slopes at the Southern Mountain in Regencies of Bantul, Gunung Kidul and Sleman.

Based on geological field investigation, it can be identified that landslides in Central Java mostly occured as the sliding or falling/ rolling of rock mass such as of bedded or jointed rocks, fig. 4 , as well as the sliding or flowing of soils and/or mixture of rock and soil masses, fig. 5, with a high rate of movement up to $25 \mathrm{~m} /$ second. These rapid landslide types mostly occur in steep mountains and hillslopes (with $30^{\circ}$ to $60^{\circ}$ slope inclination), and they result in a lot of fatalities and casualties. Indeed, rain-induced landslide disasters have resulted in 1211 fatalities, hundreds of casualties and a substantial socio-economical loss since the year 2000. On the other hand, slow movement of soil mass, such as soil

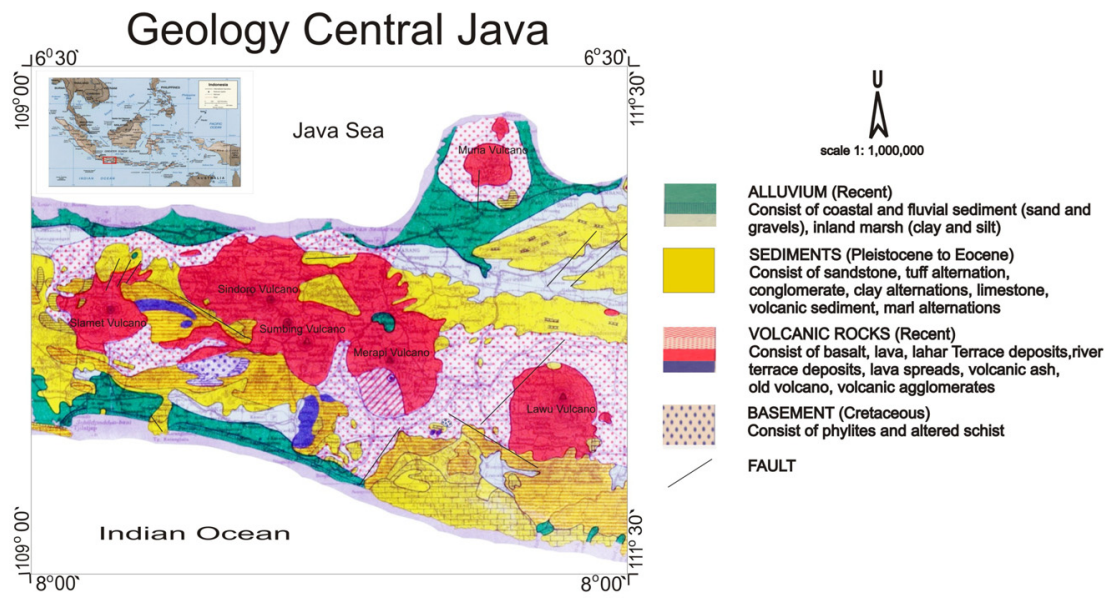

Figure 1: Geological map of Central Java modified from G.S.G.S. [1]; Surono and Sudarno (Surakarta-Giritontro Sheet) [2]; Sampurno and Samodra (Ponorogo Sheet) [3]. 


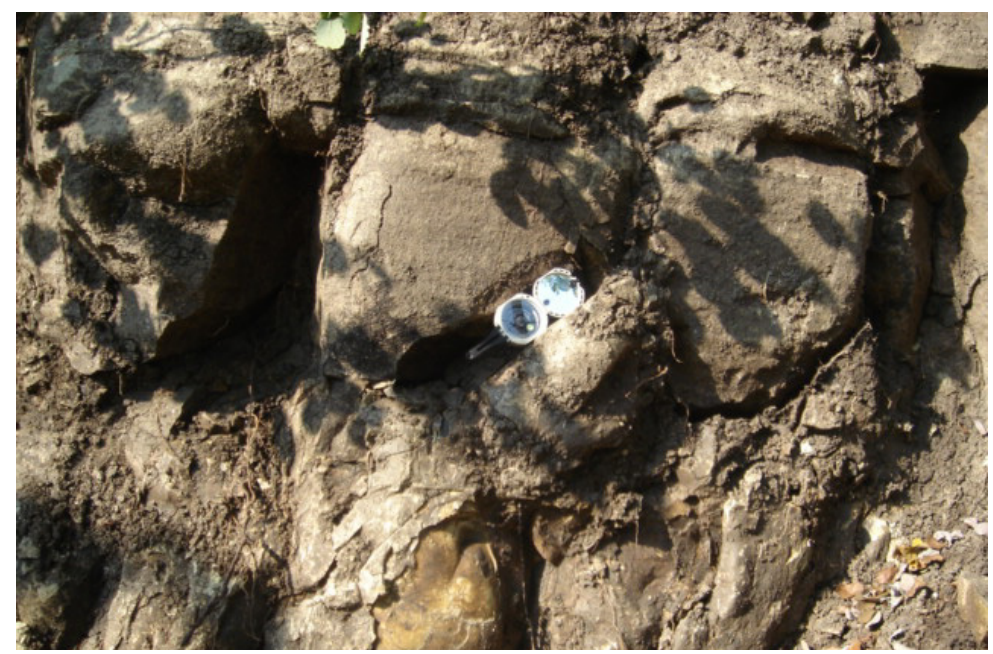

Figure 2: Jointed tufaceous sandstone, which is susceptible for rock sliding or falling exposed in Sengir Village, Sleman Regency after the earthquake of May 27, 2006.

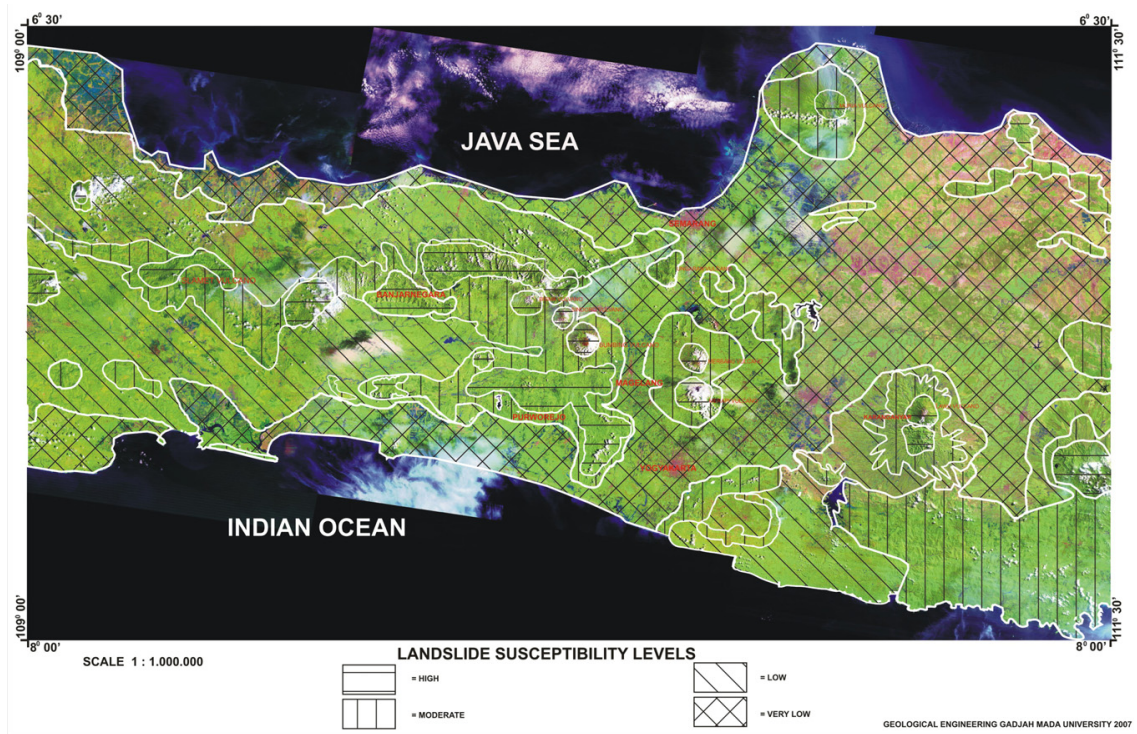

Figure 3: Landslide susceptibility map of Central Java developed based on satellite image interpretation.

creep, has never caused any fatalities but destroyed masses of land and houses at the foot of mountains or hills, fig. 6. This slow movement is mainly induced by the saturation of sensitive clay layers in the slope, which are rich in montmorillonite (smectite and/ or illite). 

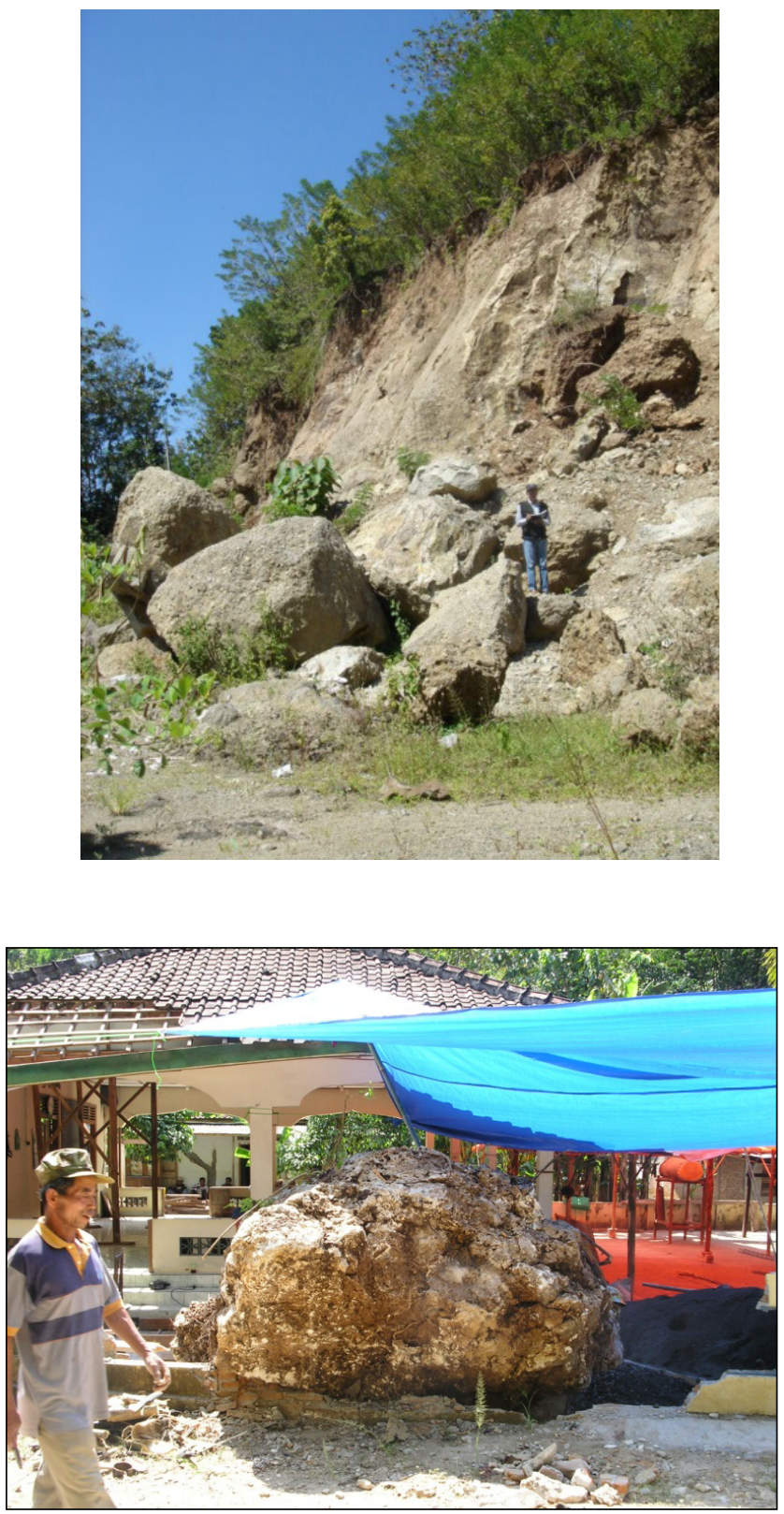

Figure 4: $\quad$ Earthquake induced rock fall in Bantul Regency in May 2006. 

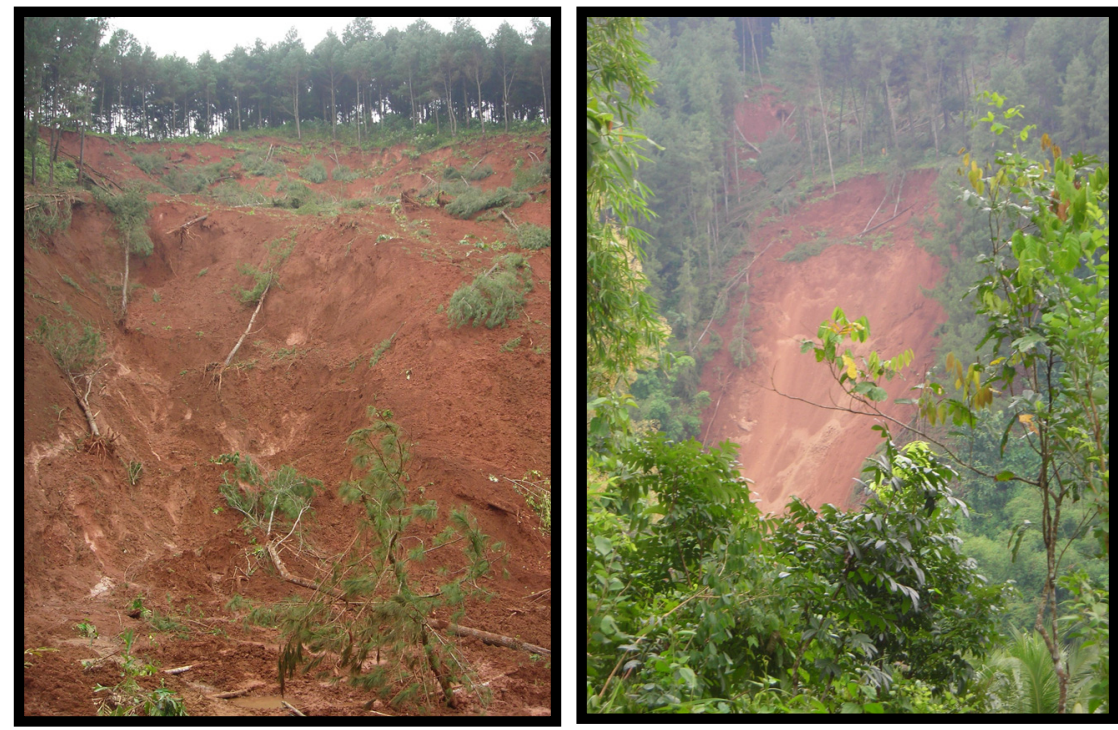

Figure 5: Earth slide (sliding of soil) in Garungang Village, Cimanggu District, Cilacap Regency, occurring in February 2009.
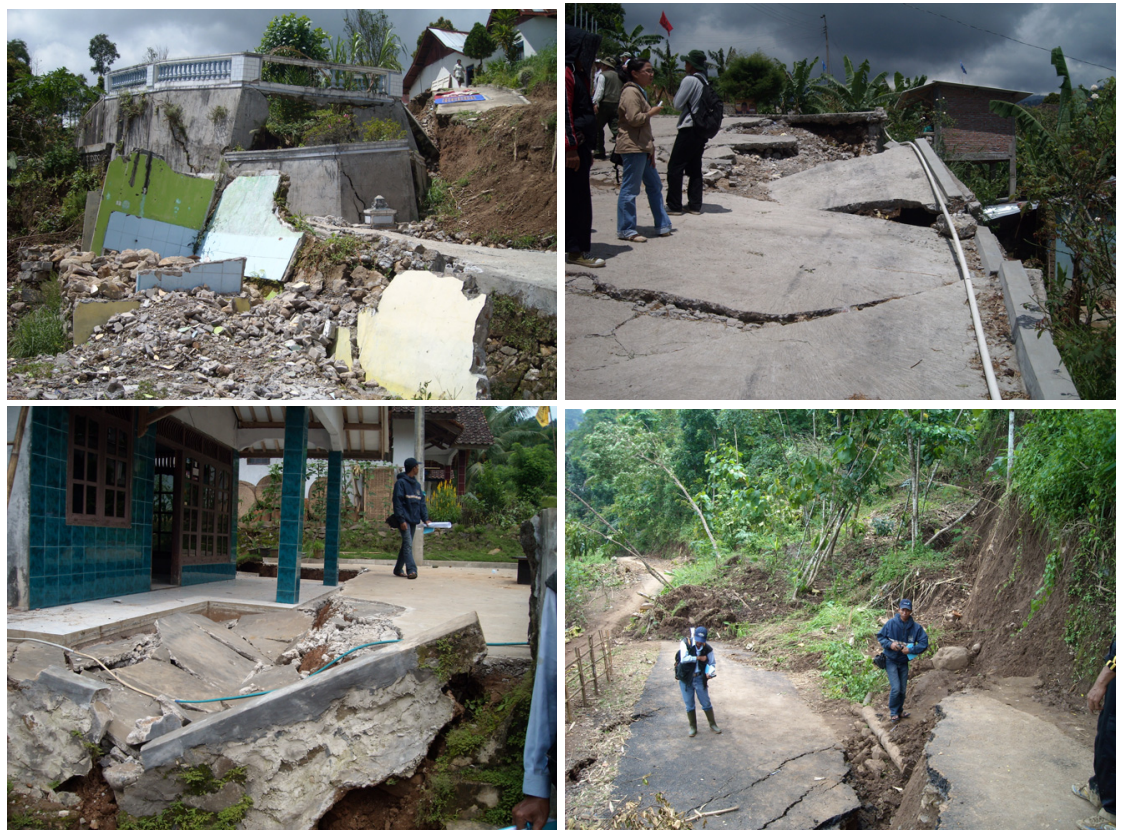

Figure 6: $\quad$ Soil creep which destroyed houses and infrastructure in Tengkllik Village at Karanganyar Regency (top) and in Cimanggu District at Cilacap Regency (bottom) on February 2009. 


\section{Socio-economical vulnerability}

It was apparent that most of the landslide prone areas have been developed with inappropriate land use management. Such areas are normally situated on slopes or at the foot of mountains, covered by thick fertile soils with plenty of water resources and a beautiful panorama. Those conditions attract more and more people to stay and to cultivate the land without having proper landslide awareness. Indeed, more and more landslide prone areas have grown as a densely-populated zone.

Based on the social survey conducted in several selected landslide prone areas, it was found that most of the community living in those areas did not have appropriate knowledge about landslide phenomena nor had immediate access to obtain information for landside mitigation, prevention and early warning. Despite the availability of landslide hazard map established by the national government which provides information about the distribution of landslide susceptibility zone, it is still not yet well-disseminated in an appropriate scale for local mitigation and is too technical, so it was quite hard for the community to understand such information. Indeed, more and more strategic infrastructures have been developed in landslide prone areas with poor consideration for landslide mitigation and early warning systems. Uncontrolled cutting of susceptible slopes for housing, road, and land cultivation is commonly done because of quite limited areas available for landuse development.

Obviously, all the above conditions bring about high socio-economical vulnerability which increases the risk of landslide disasters. Moreover, illegal logging of trees and forest, as well as uncontrolled mining excavation intensify the vulnerability of the landslide prone area.

\section{Strategy for landslide disaster risk reduction}

It was apparent that Central Java is considered as a high risk area for landslide disaster due to the susceptibility of natural conditions such as geology and climate conditions, as well as due to high vulnerability of the socio-economical conditions in landslide prone areas. Admitedly, it is impossible to change the natural conditions in order to reduce the landslide susceptibility, but it will be more feasible to manage the social conditions for reducing socio-economical vulnerability in landslide prone areas. Therefore, landslide disaster risk reduction in Central Java was conducted by adaptive management as suggested by Andayani et al. in [6], which emphasizes vulnerability reduction for community resilience improvment, through both technical and social approaches.

It was also identified that a gap of knowledge and skill between national and local government/communities is one significant obstacle in disaster risk reduction efforts. This gap crucially results in ineffective implementation of disaster risk reduction programs at a local level. Thus, community empowerment and capacity development at the village level was considered to be the most critical driving force for the success of disaster risk reduction programs. 


\section{Technical-strategic approach}

The technical approach was carried out by mainly focusing on providing an immediate access of information related to landslide mitigation and prevention for the local government and community.

It was suggested in [7] that the development of a landslide hazard or the landslide susceptibility map with a medium scale such as $1: 25,000$ illustrated in fig. 7-top is crucial for spatial prediction of landslide susceptibility, in order to facilitate an appropriate development of a landuse management plan at the district and village levels. Accordingly, the development of any infrastructure, houses and services at the zone with high landslide susceptibility should be avoided or minimized, unless, a special engineerng countermeasure is provided. Furthermore, a landslide risk map at the same scale $(1: 25,000)$ as illustrated in fig. 7-bottom was also required to estimate the potential socio-economical impacts of any probable landslide occurrence, so that the appropriate landslide risk management can be prepared. However, to ensure that both technical hazard and risk maps can be easily understood and used by the local community for landslide disaster risk reduction, a community landslide hazard and risk map at the local village-scale was required to be developed through community participation. Once the high susceptibility zone can be identified from a landslide hazard map, an appropriate landslide prevention program can be developed. Considering that the coverage area of a landslide susceptible zone was quite large whilst the budget available for landslide prevention was limited, the application of bio-engineering combined with an appropriate drainage system and simple engineering structures was considered to be the most efficient and effective for landslide prevention. It was also recommended that existing indigeneous technology and traditional knowledge should be addressed as well, in order to guarantee the effectiveness of landslide prevention programs.

\section{Social-strategic approach through capacity development}

\subsection{Public education for disaster risk reduction and sustainable development}

In order to ensure that landslide disaster risk reduction at the local village can be performed effectively, the village community should be empowered to enable them to participate actively in the disaster management program. Therefore, public education for community empowerment was conducted. It is crucial that such empowerment is not only driven for the disaster risk reduction efforts but also is directed with respect to the sustainable development and livelihood improvement in landslide a prone area.

The public education was specifically designed for the development of practical knowledge about landslide phenomena such as the cause of landslide, how to recognize the susceptible zone and the symptoms of landslide, how to prevent and control landslide occurrence, how to maintain and protect the slope and the village environment so that landslides and other related disasters can be 

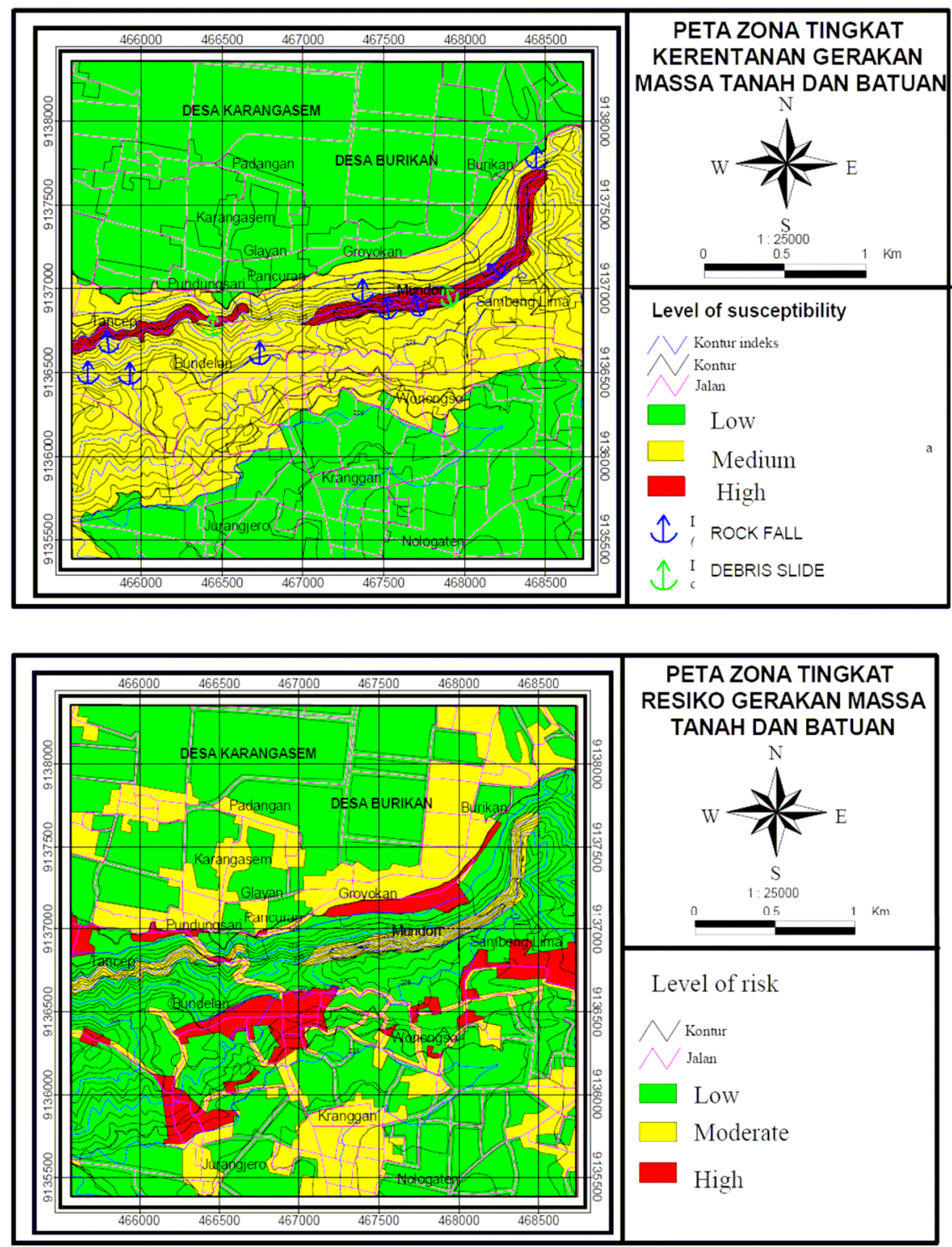

Figure 7: Landslide susceptibility map (top) and risk map (bottom) of Mundon Village Area, Gunung Kidul Regency developed by Mahendra and Karnawati in [7].

avoided. Achievement motivation training was also conducted to increase the community awareness and willingness for successfully conducting landslide prevention program. 


\subsection{Establihsment of community task force for disaster mitigation and management}

In order to sustain the community disaster mitigation and management in the landslide prone village, a community task force needs to be established as a key driving force in conducting the village disaster management program $[8,9]$. This community task force team may include the head of the village as the team leader, the representatives from local community groups, and the young leaders. This team has an important roles for a continuing public education and community empowerment program, as well as for coordinating the village disaster management program within the village community and with the district/regency disaster task force. One of hardest challenges for ensuring the active performance of this task force is about the continuing spirit and willingness of the community task force in conducting their mission without any financial rewards. A socio-cultural approach such as through traditional and/or spiritual media needs to be addressed to support the sustainability and effectivity of a community task force in conducting the mission for village-disaster management.

\section{Socio-technical strategic approach: community-based landslide early warning system}

Ideally, a zone with high susceptibility and risk of landslide should be prevented from any development, such as for the development of housing and infrastructures. Unfortunately, it is quite often that this particular zone has been developed as dense-settlement of housing and infrastructure areas, and the relocation of people living in this particular area to the saver zone cannot be conducted due to some socio-economical constraints. Thus, the development of a landslide early warning system becomes very critical to protect the people living in that particular landslide risk area.

Therefore, it is important that the landslide early warning system should be performed with a low cost and simple technology that can be easily understood, operated and maintaned by the local community, such as suggested by Karnawati et al in [9] and by Fathani et al. in [10]. Indeed, such system should be the integration of technical and social systems. The technical system consists of simple extensometers, i.e. to monitor the ground-surface movement with the accuracy of $0.1 \mathrm{~mm}$, and a rain-gauge used to monitor the critical rainfall which can induce landsliding with the accuracy of $1 \mathrm{~mm}$, fig. 8. Meanwhile the social system is supported by the network of selected individuals who are assigned by the local community in the village as the member of community task force for disaster mitigation and management (as discussed in Section 5.2), and this team is responsible for the installation, operation and maintenance of the technical system. For instance, the system which has been installed in two selected sites in Central Java consisted of 5 extensometers and 1 rain-gauge for each site with an area of about 50 to 75 hectares, and supported by 15-man-power selected from 5 housing groups in each site. To provide an early warning, an alarm is connected 
to each piece of equipment in the system and the alarm is automatically set to be "on" when critical rainfall which can induce landsliding and/or critical conditions of slope movement occurs. To set the alarm to be on at the appropriate time, all of those pieces of equipment are generated by dry batteries and/or solar energy which can work effectively during heavy rainfall when the electricity power does not work properly. The village action plan (including the contingency plan) for disaster prevention and response program is accordingly developed by this task force team. Obviously, one of the most important programs to guarantee the effectiveness in implementing this early warning system in the village is public education and evacuation drill such as that illustrated in fig. 9. Those programs need to be conducted regularly to improve the awareness and readiness of local community for any possible landslide disaster. In fact, this simple early warning system has successfully saved 35 families from a landslide which occurred in Kalitelaga village at Banjarnegera Regency on November 7, 2007, such as reported by Karnawati et al. in [9].
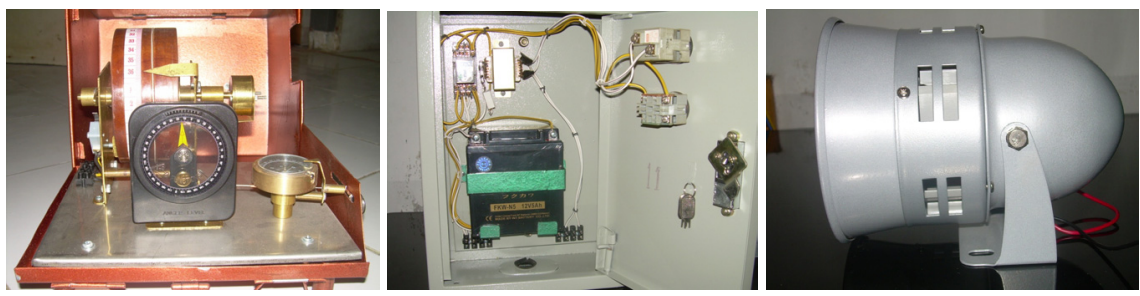

Figure 8: Extensometer (left) with the dry batteray (center) and alarm siren (right) in [9].
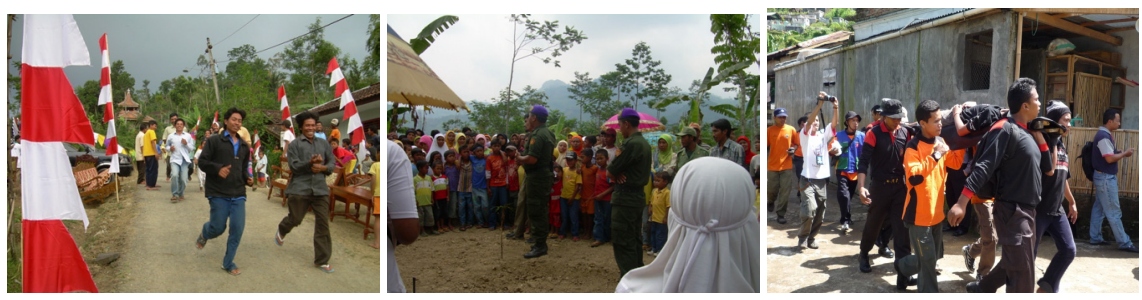

Figure 9: Evacuation drill (left) and the coordination with the local rescue team (center and right).

\section{Conclusion}

Despite the natural conditions which are susceptible for landslide occurrence, potential landslide disaster in Central Java can be reduced with more emphasis on the management of social vulnerability. Indeed, this disaster risk reduction effort needs to be supported by both technical and social approaches. The technical approach is required to provide facilities for immediate access in 
landslide mitigation/prevention, whilst the social approach should mainly directed for the capacity development of the local community in the village. Accordingly, an integrated approach of both a technical and social system should be conducted to establish an effective community early warning system. Through all of these strategic approaches, community resilience in disaster-prone areas at village level can be effectively improved. It is also very crucial to especially address the traditional wisdom and indigenous-simple technology in both technical and social approaches for disaster risk reduction. Finally, it should be admitted that the success of disaster risk reduction at the local or at village level is the key-success for the disaster risk reduction program at a national level.

\section{Acknowledgements}

The authors would like to express their gratitude to the DelPHe Project funded by the British Council for providing financial support to carry out the action research presented in this paper. Special acknowledgement is also directed to the WCRU Program of Gadjah Mada University for providing the sponsorship to participate in this Disaster Management 2009 Conference.

\section{References}

[1] G.S.G.S., Geology of Central Java, Sheets S B 48, 49, 50, SC 49, 50. $2^{\text {nd }}$ ed. Photographed by War Office: USA, 1944.

[2] Surono, Toha, B. \& Sudarno I., Geology of Surakarta-Giritontro, Geological Research and Development Centre: Indonesia, 1992.

[3] Sampurno \& Samodra, H., Geology of Ponorogo, Geological Research and Development Centre: Indonesia, 1997.

[4] Karnawati, D., Ibriam, I., Anderson, M.G., Holcombe, E. A., Mummery, G.T., Renaud, J.P \& Wang, Y., An initial approach to identifying slope stability controls in Southern Java and to providing community-based landslide warning information. Landslide Hazard and Risk, eds. T. Glade, M.G. Anderson \& M. J. Crozier, John Wiley and Sons: New York, pp. 733-763. 2005.

[5] Karnawati, D. \& Fathani, T. F., Mechanism of earthquake induced landslides in Yogyakarta Province, Indonesia. The Yogyakarta Earthquake of May 27, 2006, eds. D. Karnawati, S. Pramumijoyo, R. Anderson \& S. Hussein. Star Publishing Company Inc.: Belmont, CA., pp. 8-1 to 8-8, 2008 .

[6] Andayani, B., Karnawati, D. \& Pramumijoyo, S., Institutional frame work for community empowerment towards landslide mitigation and risk reduction in Indonesia. Proc. of the $1^{\text {st }}$ World Landslide Forum, Global Promotion Committee of the Int. Program on Landslide (IPL) - ISDR: Tokyo, pp. 57-59. 2008.

[7] Karnawati, D. \& Burton, P.W., Seismicity and Landslide Research towards Public Empowerment for Hazard Preparedness; First Year Annual Report of Development Partnership in Higher Education 
(DelPHE) - the British Council, Geological Engineering Department, Faculty of Engineering, Gadjah Mada University-School of Environmental Sciences, University of East Anglia: Indonesia and UK. 2008.

[8] Karnawati, D., Pramumijoyo, S., Andayani, B. \& Burton, P.W., Earthquake \& landslide hazard mapping for community empowerment. Proc. of the $51^{\text {st }}$ Annual Meeting Assoc. of Engineering and Environmental Geologist: New Orleans, 2008.

[9] Karnawati, D., Fathani, T.F., Sudarno, I. \& Andayani, B., Development of community-based landslide early warning system in Indonesia. Proceeding of the $1^{\text {st }}$ World Landslide Forum, Global Promotion Committee of The Int. Program on Landslide (IPL) - ISDR: Tokyo, pp. 305-308. 2008.

[10] Fathani, T.F., Karnawati, D., Sassa, K. \& Fukuoka, H. Development of landslide monitoring and early warning system in Indonesia. Proc. of the $1^{\text {st }}$ World Landslide Forum, Global Promotion Committee of The Int. Program on Landslide (IPL) - ISDR: Tokyo, pp. 195-198. 